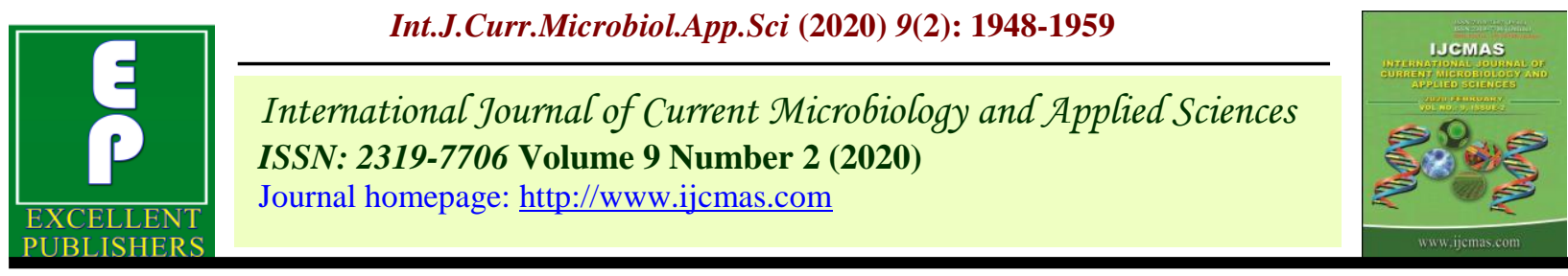

Review Article

https://doi.org/10.20546/ijcmas.2020.902.222

\title{
Maize Genetic Diversity: Utilization of Molecular Markers in Genetic Diversity
}

\author{
Anand Kumar ${ }^{1 *}$ and Vivudh Pratap Singh ${ }^{2}$ \\ ${ }^{1}$ Department of Genetics and Plant Breeding, Chandra Shekhar Azad University of \\ Agriculture and Technology, Kanpur (Uttar Pradesh), 208002 \\ ${ }^{2}$ Department of Genetics and Plant Breeding, Chaudhary Charan Singh University, Meerut \\ (Uttar Pradesh), 250004, India \\ *Corresponding author
}

\begin{tabular}{|c|c|}
\hline & A B S T R A C T \\
\hline & \multirow{6}{*}{$\begin{array}{l}\text { Maize is one of thecereals grown under world wide area. Global ranking of maize } \\
\text { is having third rank in among cereals. It's main utilization as a form of food and } \\
\text { fodder in all over world. Maize consumed by the human and it has income source } \\
\text { of majority overwhelming population. It is also used by the industrial product such } \\
\text { as corn starch and other things. Maize having good properties for food calorie 30- } \\
60 \% \text { and dietary protein, that is very easy digestible for human. cultivated maize } \\
\text { is developed from the teosinte maize, teosinte maize having good resietance for } \\
\text { biotic and abiotic factor, but new cultivated species has been deteriorate due to } \\
\text { modernization of cultivation. So to maintain the genetic diversity in maize, need } \\
\text { some necessary work.Genetic diversity is the total variability present in individual } \\
\text { or organism/population. Due to continuous use of maize variety in field and } \\
\text { enhance the modern technology has deteriorated potential of genetic diversity.So } \\
\text { to conserve this diversity in nature, need to study on population or inbreds } \\
\text { (Dubreuil and Charcosset 1999). Genetic diversity such as morphological, } \\
\text { biochemical and other molecular characterizations are available (Govindaraj et al., } \\
\text { 2015). Morphological and biochemical method has been extensively used (Franco } \\
\text { et al., 2001), but these methods are highly sensitive to environmental (Smith and } \\
\text { Smith 1992; Beyenne et al., 2006). Molecular marker has scattered all over } \\
\text { population to know about relationship among variety or genetic diversity. } \\
\text { Molecular marker has been only based on DNA technology such as SSR, SNPs, } \\
\text { RAPD and AFLP etc. }\end{array}$} \\
\hline & \\
\hline & \\
\hline Article Info & \\
\hline & \\
\hline & \\
\hline
\end{tabular}

\section{Introduction}

Maize (Zea maize L.) belongs to poaceae family and it is cultivated all over world.
Global ranking of maize has third ranked all over worldwide their own productivity and significance utilization in a form of food and fodder (first and second is rice and wheat 
respectively). Maize used by human, and it has also income source of majority overwhelming population (EARO 2000). It used as a form of industrial product such as starch based product, corn starch and other things. Heavy use of maize and maize product, maize demanding has been increased day by day continue in all over world (Wada et al., 2008). Maize having good properties for food calorie about 30-60 \% and also having dietary protein, that is very easy digestible for human.

Its grain is produced for several other dishes and consumed by the human (Showemimo et al., 2007).Now days hybrid (Zea mays L.) is most widely cultivated spp. all over world due to more high yield compare to other variety of maize and it has economically differ from other maize however other varieties of maize has diversified characters on other variety.

Maize populations grow on several climates such as tropical and sub-tropical climate (Rebourg et al., 2003; Dubreuil et al., 2006). In ancient time landraces was very popular, but now day's farmers variety and other local varieties are existing: landraces are very resistance to biotic and abiotic factor and it has more diversified than others having heterogeneous nature and selected by the farmers for cultivation (Prasanna and Sharma 2005).

But due to low yield, landraces did not cultivated by the farmers for longer time. Cultivated maize is developed from the teosinte maize (Zea mays purviglumys) and it is distinguished from teosinte maize their morphology and other characters (Wang et al., 1999; Matsuoka et al., 2002; Doebley, 2004; Vigouroux et al., 2005).

To develop good hybrid variety of maize should be good knowledge all about relationship among in the variety to conserve
germplasm(Melchinger et al., 1991; Bernardo 2002).

Genetic diversity is the total variability present in individual or organism/population. Due to continuous use of maize variety in field and enhance the modern technology has deteriorated potential of genetic diversity. A Loss of genetic diversity in nature due to continue use of homogeneity related variety that is not present in nature, developed by the human effort. So to conserve this diversity in nature, need to study on population or inbreds (Dubreuil and Charcosset 1999).

There are many study has been conducted on analysis of genetic diversity such as morphological, biochemical and other molecular characterizations are available (Govindaraj et al., 2015). Morphological and biochemical method has been extensively used (Franco et al., 2005), but these methods are highly sensitive to environmental effects (Smith and Smith 1992; Beyenne et al., 2006a).

Molecular marker has scattered all over population to know about relationship among variety.Molecular marker has been only based on DNA technology such as SSR, SNPs, RAPD and AFLP etc. (Govindaraj et al., 2015).And expression of molecular marker is not influenced by the environment, and it also avoiding genotypic $\times$ environmental effects and reveals the actual level of different population through analysis with the help of molecular marker (Westman and Kresovich 1997).

There are several population has been used for QTL mapping such as mortal and immortal population, in mortal population(can be segregate) such as $\mathrm{f}_{2}$ population and $\mathrm{BC}$ (back cross) population, but immortal population (cannot be segregate) having such as DH (doubled haploid), RIL (Recombinant 
inbred lines), $\mathrm{F}_{2}$ derived lines, NIL (near isogenic lines) and other population extensively has been used for QTL identification (Byrne et al., 1996; Cowen 1988; Edwards et al., 1992, 1987; Knapp 1991; Knapp and Bridges 1990; Tanksley et al., 1982) (Szalma et al2007).

Genotyping with the help of molecular marker is very crucial role to discriminate desirable Genotype from undesirable ones in many individuals or organism. There are many reliable technology has been participated for better characterization of desirable genotype from breeding material. There are many marker systems has been extensively used to analyze the genetic diversity and molecular marker assisted selection (Elisabetta Frascaroli - Tobias A. Schrag • Albrecht E. Melchinger 2013).

\section{Classification of marker}

Marker in plant breeding have been utilized to know, genetic diversity, genome mapping, QTL mapping and for genotyping etc. so marker play indispensible role in plant breeding. To aggregate knowledge of molecular marker is a difficult task, but it is an easy.

\section{SSR or microsatellite}

SSR also called the microsatellite marker, it consist of tandem repeat in DNA sequence such as mono, di, tri, tetra and so on. This tandem repeats found in both prokaryotic and eukaryotic genome (Tautz and Renz 1984; Katti et al., 2001). It have another name such as short tandem repeats marker, microsatellites markers and sequence tagged microsatellite (STMS) marker etc. it is hyper variable marker that is available in nature (Jiang 2013). The variation in these markers has been only due to subside the DNA replication, in this, there are many tandem repeats of nucleotide may be matching due to excision or addition repeats of DNA (Schlotterer and Tautz 1992). Slippage of DNA strand during replication originate more time than the point mutation. Polymorphism can be analyzed with the help of PCR.

In this technique primer used without radioactive labeled or flurolabeled or radiolabeled to know diverse group of individual.This unlabeled primer is used to analyze with the help of agarose gel electrophoresis or polyacrylamide gel.

The unlabeled or fluorolabed primer significantly enhances the research (Wenz et al., 1998). SSR or microsatellite is codominant in nature and distinguished to heterozygous from homozygous and they are also highly reproducible due to locus specific (see table no. 01). These primers mostly used in both eukaryotic and prokaryotic (Khanet al., 2017).

\section{Application of SSR marker}

It is used in genetic diversity, characterization of germplasm, development of genetic linkage map and also used to identification of QTL detection (Hiremath et al., 2012). The locus specific study has been conducted in many plant species such as barley (Saghai Maroof et al., 1994), jute (Das et al., 2012), wheat (Mukhtar et al., 20O2), chickpea (Nayak et al., 2010), Alfalfa (Li et al., 2009), barley (Saghai Maroof et al., 1994) and also has been study on rice ( $\mathrm{Wu}$ and Tanksley 1993) etc.

\section{SNP}

Single nucleotide variation arises due to single nucleotide in a genome in individuals of a population knows as SNPs. These variations found in among species, it varies individual to individuals and they constitute the more sufficient marker in the genome. 
Table.1 Schematic representation of marker that has been more used in genetic diversity in maize

\begin{tabular}{|c|c|c|c|c|c|}
\hline S.NO. & $\begin{array}{l}\text { MARKER } \\
\text { TYPE }\end{array}$ & TRAIT & $\begin{array}{l}\text { GENE/ } \\
\text { QTL }\end{array}$ & $\begin{array}{l}\text { MAPPING } \\
\text { POPULATION }\end{array}$ & REFERENCES \\
\hline 01 & SSR & $\begin{array}{l}\text { Grain yield (gy), plant } \\
\text { height, ear height and } \\
\text { grain moisture }\end{array}$ & 13 & $400 \mathrm{~F} 2: 3$ lines & Sibov et al., 2003 \\
\hline 02 & SSR & plant height & 13 & $\begin{array}{l}294 \text { recombinant } \\
\text { inbred lines }\end{array}$ & Ji-hua et al., 2007 \\
\hline 03 & SSR & $\begin{array}{l}\text { Grain Yield and Plant } \\
\text { Traits }\end{array}$ & 16 & 256, F2:3 families & Lima et al., 2006 \\
\hline 04 & SSR & $\begin{array}{l}\text { Root aerenchyma } \\
\text { formation }\end{array}$ & 04 & $141 \mathrm{~F} 2$ population & Mano et al., 2007 \\
\hline 05 & SSR & $\begin{array}{l}\text { oil, starch, and protein } \\
\text { concentrations in grain }\end{array}$ & 25 & $\begin{array}{l}298 \mathrm{~F} 2: 3 \\
\text { family }\end{array}$ & Zhang et al., 2007 \\
\hline 06 & SSR & $\begin{array}{l}\text { gray leaf } \\
\text { spot }\end{array}$ & 14 & 37 inbred lines & Danson et al., 2008 \\
\hline 07 & SSR & agronomic traits & 51 & 450 maize RILs & Guo et al., 2008 \\
\hline 08 & SSR & Root traits & 17 & 94 Ril & Liu et al., 2008 \\
\hline 09 & SSR & $\begin{array}{l}\text { Northern leaf blight } \\
\text { Resistance }\end{array}$ & 36 & $400 \mathrm{~F} 2: 3$ progenies & Sabadin et al., 2008 \\
\hline 10 & SSR & Fusarium ear rot & 16 & 187 Ril & Ding et al., 2009 \\
\hline 11 & SSR & Phosphorus treatments & 69 & 210, F2:3 families & Li et al., 2019 \\
\hline 12 & SSR & Kernel row number & 13 & $\begin{array}{l}500, \mathrm{~F} 2 \\
\text { Individuals }\end{array}$ & Lu et al., 2010 \\
\hline 13 & SSR & grain oil and starch & 21 & 265 F2:3 families & Wang et al., 2010 \\
\hline 14 & SSR & Test weight & 5 & $225 \mathrm{~F} 2: 3$ population & Ding et al., 2011 \\
\hline 15 & SSR & $\begin{array}{l}\text { Resistance } \\
\text { To Aflatoxin }\end{array}$ & 40 & 250, F2:3 families & $\begin{array}{l}\text { Warburton et al., } \\
2011\end{array}$ \\
\hline 16 & SSR & $\begin{array}{ll}\text { Root } & \text { system } \\
\text { architecture } & \end{array}$ & 36 & $\begin{array}{l}187 \text { advanced- } \\
\text { backcross } \\
\text { BC4F3 }\end{array}$ & Cai et al., 2012 \\
\hline 17 & SSR & gray leaf spot & & $161 \mathrm{~F} 2: 3$ families & Zhang et al., 2012 \\
\hline 18 & SSR & $\begin{array}{l}\text { agronomic traits } \\
\text { associated with plant } \\
\text { architecture }\end{array}$ & 18 & 239, RIL & $\begin{array}{l}\text { Zheng and Liu } \\
2013\end{array}$ \\
\hline 19 & SSR & $\begin{array}{l}\text { kernel size } \\
\text { and weight }\end{array}$ & 55 and 28 & $\begin{array}{l}270 \text { derived } F 2: 3 \\
\text { families }\end{array}$ & Liu et al., 2014 \\
\hline 20 & SSR & $\begin{array}{l}\text { Gray leaf spot } \\
\text { resistance }\end{array}$ & 18 & $478 \mathrm{~F} 2: 3$ population & Liu et al 2015 \\
\hline 21 & SSR & Ear Fasciation & 65 & $149 \mathrm{~F} 2: 3$ families & Moreira et al., 2015 \\
\hline 22 & SSR & $\begin{array}{l}\text { the protein, oil and } \\
\text { starch contents }\end{array}$ & $\begin{array}{c}25,13, \\
31 \text { and } 15\end{array}$ & 498 RILs & Zhang et al., 2015 \\
\hline
\end{tabular}




\begin{tabular}{|c|c|c|c|c|c|}
\hline 23 & SSR & $\begin{array}{l}\text { Grain morphology } \\
\text { traits }\end{array}$ & $\begin{array}{c}18,26, \\
23, \text { and } 19\end{array}$ & 58 , Ril & Raihan et al., 2016 \\
\hline 24 & SSR & Grey leaf spot & 12 & 233 f2:3 families & He et al., 2017 \\
\hline 25 & SSR & $\begin{array}{l}\text { inflorescence } \\
\text { architecture }\end{array}$ & 19 & $\begin{array}{l}202 \text { and } 218 \quad F 2: 3 \\
\text { family }\end{array}$ & Zhao et al., 2017 \\
\hline 26 & SSR & Agronomic traits & 15 & $121 \mathrm{Dh}$ population & Choi et al., 2018 \\
\hline 27 & SSR & $\begin{array}{l}\text { Maize kernel size } \\
\text { And weight }\end{array}$ & 52 & $150 \mathrm{f} 7$ rils & Lan et al., 2018 \\
\hline 28 & SSR & $\begin{array}{l}\text { Forage agronomic } \\
\text { traits }\end{array}$ & $\begin{array}{l}42, \\
41,54, \\
\text { and } 45\end{array}$ & $\begin{array}{l}250-720 \text { Doubled } \\
\text { Haploid lines (dhl), } \\
\text { and ril population }\end{array}$ & Leng et al., 2018 \\
\hline 29 & SSR & $\begin{array}{l}\text { Nitrogen } \\
\text { efficiency (nue), }\end{array}$ & 19 & $\begin{array}{l}\text { Recombinant inbred } \\
\text { lines (181) }\end{array}$ & $\begin{array}{l}\text { Mandolino et al. } \\
2018\end{array}$ \\
\hline 30 & SSR & Kernel weight & 28 & 40, F2:3 population & Li et al., 2019 \\
\hline 31 & SNP & Northern leaf blight & 29 & 25,Nam, ril & Poland et al., 2011 \\
\hline 32 & SNP & $\begin{array}{l}\text { SOUTHERN LEAF } \\
\text { BLIGHT }\end{array}$ & 32 & 5000 RIL & Kump, et al., 2011 \\
\hline 33 & SNP & $\begin{array}{l}\text { plant height and } \\
\text { biomass as secondary } \\
\text { traits of drought } \\
\text { tolerance }\end{array}$ & 23 & $150 \mathrm{~F} 2: 3$ line & Lu et al., 2011 \\
\hline 34 & SNP & Head smut & 18 & 144, Inbred lines & Wang et al2012 \\
\hline 35 & SNP & $\begin{array}{l}\text { Kernel Weight } \\
\text { Determination }\end{array}$ & 23,59 & $\begin{array}{l}408 \text { recombinant } \\
\text { inbred lines }\end{array}$ & Prado et al., 2014 \\
\hline 36 & SNP & $\begin{array}{l}\text { Fusarium ear } \\
\text { Rot resistance }\end{array}$ & 15 & $\begin{array}{l}940 \text { elite inbred } \\
\text { lines }\end{array}$ & Chen et al2016 \\
\hline 37 & SNP & leaf morphology & 111 & $\begin{array}{l}\text { 215, 223, } 208 \text { and } \\
\text { 212 RILs }\end{array}$ & Ku et al., 2016 \\
\hline 38 & SNP & ear leaf traits & $\begin{array}{l}23,25, \\
\text { and } 17\end{array}$ & 909 ril & Wang et al., 2017 \\
\hline 39 & SNP & Vitamin E & 31 & $213 \mathrm{~F} 2: 3$ & Fenton et al., 2018 \\
\hline 40 & SNP & amylose biosynthesis & 27 & $\begin{array}{l}464 \text { inbred maize } \\
\text { lines }\end{array}$ & Li et al., 2018 \\
\hline 41 & SNP & $\begin{array}{l}\text { Genetic } \\
\text { Architecture Of Leaf } \\
\text { Angle And Tassel Size }\end{array}$ & 23 & 213 F2:3 Population & Liu et al., 2018 \\
\hline 42 & SNP & $\begin{array}{l}\text { Cob resistance, ear } \\
\text { Rot resistance }\end{array}$ & 28 & $\begin{array}{l}258 \\
\text { Maize inbred }\end{array}$ & Mu et al., 2018 \\
\hline 43 & SNP & tassel-related traits & 27 & 266 F2:3 families ril & YI et al., 2018 \\
\hline 44 & SNP & Common rust & 25 & F2:3 population & Zheng et al., 2018 \\
\hline 45 & SNP & Leaf morphology traits & 19,838 & $\begin{array}{l}866 \text { maize-teosinte } \\
\text { bc } 2 \text { s } 3 \text { recombinant } \\
\text { inbred lines }\end{array}$ & Fu et al., 2019 \\
\hline 46 & SNP & Starch content & 9076 & 283 intermated & Lin et al., 2019 \\
\hline
\end{tabular}




\begin{tabular}{|c|c|c|c|c|c|}
\hline & & & & $\begin{array}{l}\text { recombinant inbred } \\
\text { lines (rils) }\end{array}$ & \\
\hline 47 & SNP & Salt tolerance & 65 & $\begin{array}{l}209 \text { doubled } \\
\text { Haploid (dh) }\end{array}$ & Luo et al., 2019 \\
\hline 48 & SNP & $\begin{array}{l}\text { Southern leaf blight, } \\
\text { northern leaf blight, } \\
\text { and gray leaf spot }\end{array}$ & 44 & $\begin{array}{l}\mathrm{F} 2: 3 \text { family } \\
\text { populations } 12\end{array}$ & Martins et al., 2019 \\
\hline 49 & SNP & $\begin{array}{l}\text { Delayed maize } \\
\text { flowering in response } \\
\text { to low } \\
\text { Phosphate }\end{array}$ & 41 & 262 Ril population & Ren et al., 2019 \\
\hline 50 & SNP & $\begin{array}{l}\text { Water } \\
\text { responsive }\end{array}$ & 213 & 267 Ril population & $\begin{array}{l}\text { Virlouvet et al., } \\
2019\end{array}$ \\
\hline 51 & SNP & Dynamic plant height & 68 & $\begin{array}{l}\text { Inbred lines }(117 \\
\text { temperate lines, } 135 \\
\text { tropical lines }\end{array}$ & Wang et al., 2019 \\
\hline 52 & SNP & Tassel architecture & 19 & 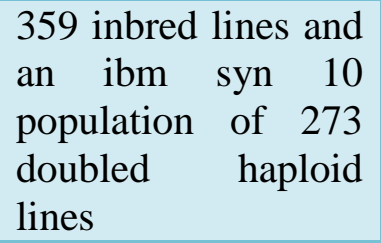 & Wang et al., 2019 \\
\hline 53 & SNP & Tassel-related traits & 14 & 148 f2 population & Xie et al., 2019 \\
\hline 54 & SNP & Plant architecture & 21 & $\begin{array}{l}301 \text { recombinant } \\
\text { inbred lines }\end{array}$ & Yi et al., 2019 \\
\hline 55 & SNP & $\begin{array}{l}\text { Disease } \\
\text { resistance(southern } \\
\text { leaf blight (slb), } \\
\text { northern leaf blight } \\
\text { (nlb), and gray leaf } \\
\text { spot) }\end{array}$ & 17 & $253 \mathrm{RIL}$ & Zuniga et al., 2019 \\
\hline
\end{tabular}

In maize 1 SNPs has been found over 60-120 bp (Ching et al., 2002), while in human has been estimated found 1 SNPs over $1000 \mathrm{bp}$ (Sachidanandam et al., 2001). SNPs are more popular in the genome that has non coding regions.

But within the coding sequence that may be changed results in the amino acid sequence either this is the non-synonymous (Sunyaev et al., 1999), or the synonymous may be not altering the amino acid sequence. Synonymous can be changed the amino acid that can be changed the RNA splicing and changed in the modification, resulting the phenotypic differences. Direct analysis of DNA genetic variation sequence has made been possible due to some changes has been improved in DNA sequencing and available of ESTs sequence in the genome (Buetow et al., 1999; Soleimani et al., 2003).

This majority is based on the two approaches molecular mechanism, hybridization of specific alleles, extension of primer and prolificacy attack and ligation of nucleotide (Sobrino et al., 2005). This is the high throughput genotyping method, allele specific PCR and extension of primer make possible single nucleotide polymorphism in any 
individuals (see table no. 01). This is the most widely accepted by the plant breeders, due to high rapid method and gives appropriate result; this is the biallelic and codominant marker etc (Agarwal et al., 2008)

Maize plays indispensible role that is consumed by human in all over worldwide. So we should be enhancing growth of maize, need some any technology that can be fulfill these criteria. So we need good technology. Genetic diversity is the total gene present in among individuals.

Modern cultivation is continuing decrease the heterogeneity. So we need to maintain the genetic diversity for future use. There are some molecular work such as marker assisted selection with the help of marker can be detect the genetic diversity present in among individuals. There are mainly in this research paper two molecular marker such as SSR and SNPs mostly used by the many plant breeders and researchers.

\section{References}

Agarwal, M., Shrivastava, N. and Padh, H., 2008. Advances in molecular marker techniques and their applications in plant sciences. Plant cell reports,27(4), pp.617-631.

Bernardo, R., 2002. Breeding for quantitative traits in plants (Vol. 1, p. 369). Woodbury, MN: Stemma press.

Beyene, A., Gibbon, D. and Haile, M., 2006. Heterogeneity in land resources and diversity in farming practices in Tigray, Ethiopia. Agricultural systems, 88(1), pp.61-74.

Buetow, K.H., Edmonson, M.N. and Cassidy, A.B., 1999. Reliable identification of large numbers of candidate SNPs from public EST data. Nature genetics, 21(3), pp.323-325.

Byrne, P.F., McMullen, M.D., Snook, M.E., Musket, T.A., Theuri, J.M., Widstrom,
N.W., Wiseman, B.R. and Coe, E.H., 1996. Quantitative trait loci and metabolic pathways: genetic control of the concentration of maysin, a corn earworm resistance factor, in maize silks. Proceedings of the National Academy of Sciences, 93(17), pp.88208825 .

Cai, H., Chen, F., Mi, G., Zhang, F., Maurer, H.P., Liu, W., Reif, J.C. and Yuan, L., 2012. Mapping QTLs for root system architecture of maize (Zea mays L.) in the field at different developmental stages. Theoretical and Applied Genetics, 125(6), pp.1313-1324.

Ching, A.D.A., Caldwell, K.S., Jung, M., Dolan, M., Smith, O.S.H., Tingey, S., Morgante, M. and Rafalski, A.J., 2002. SNP frequency, haplotype structure and linkage disequilibrium in elite maize inbred lines. BMC genetics, 3(1), p.19.

Cowen NM (1988) The use of replicated progenies in markerbased mapping of QTL',s. Theor Appl Genet 75:857-862

Danson, J., Lagat, M., Kimani, M. and Kuria, A., 2008. Quantitative trait loci (QTLs) for resistance to gray leaf spot and common rust diseases of maize. African Journal of Biotechnology, 7(18).

Das, A., Hari, S.S., Shalini, U., Ganeshkumar, A. and Karthikeyan, M., 2012. Molecular screening of virulence genes from Salmonella enterica isolated from commercial food stuffs. Biosci Biotech Res Asia, 9, pp.363-369.

Ding, D., Zhang, L., Wang, H., Liu, Z., Zhang, Z. and Zheng, Y., 2009. Differential expression of miRNAs in response to salt stress in maize roots. Annals of botany, 103(1), pp.29-38.

Doebley, J., 2004. The genetics of maize evolution. Annu. Rev. Genet., 38, pp.3759.

Dubreuil, P. and Charcosset, A., 1998. Genetic diversity within and among maize populations: a comparison between isozyme and nuclear RFLP loci. Theoretical and Applied Genetics, 96(5), pp.577-587. 
Dubreuil, P. and Charcosset, A., 1999. Relationships among maize inbred lines and populations from European and North-American origins as estimated using RFLP markers. Theoretical and applied genetics, 99(3-4), pp.473-480.

Dubreuil, P., Warburton, M.L., Chastanet, M., Hoisington, D. and Charcosset, A., 2006. More on the introduction of temperate maize into Europe: large-scale bulk SSR genotyping and new historical elements. Maydica, 51(2), pp.281-291.

Edwards, M., 1992. Use of molecular markers in the evaluation and introgression of genetic diversity for quantitative traits. Field Crops Research,29(3), pp.241-260.

Edwards, M.D., Stuber, C.W. and Wendel, J.F., 1987. Molecular-marker-facilitated investigations of quantitative-trait loci in maize. I. Numbers, genomic distribution and types of gene action. Genetics, 116(1), pp.113-125.

Fenton, M.E., Owens, B.F., Lipka, A.E., Ortiz, D., Tiede, T., Mateos-Hernandez, M., Ferruzzi, M.G. and Rocheford, T., 2018. High-density linkage mapping of vitamin $\mathrm{E}$ content in maize grain. Molecular breeding, 38(3), p.31.

Franco, M.M., Antunes, R.C., Silva, H.D. and Goulart, L.R., 2005. Association of a PIT1, GH and GHRH polymorphism with performance and carcass traits in Landrace pigs. Embrapa Recursos Genéticos e Biotecnologia-Artigo em periódico indexado (ALICE).

Frascaroli, E., Schrag, T.A. and Melchinger, A.E., 2013. Genetic diversity analysis of elite European maize (Zea mays L.) inbred lines using AFLP, SSR, and SNP markers reveals ascertainment bias for a subset of SNPs. Theoretical and applied genetics, 126(1), pp.133-141.

Govindaraj, M., Vetriventhan, M. and Srinivasan, M., 2015. Importance of genetic diversity assessment in crop plants and its recent advances: an overview of its analytical perspectives. Genetics research international, 2015.

Govindaraj, M., Vetriventhan, M. and Srinivasan, M., 2015. Importance of genetic diversity assessment in crop plants and its recent advances: an overview of its analytical perspectives. Genetics research international, 2015.

Guo, M., Yang, S., Rupe, M., Hu, B., Bickel, D.R., Arthur, L. and Smith, O., 2008. Genome-wide allele-specific expression analysis using massively parallel signature sequencing (MPSS ${ }^{\mathrm{TM}}$ ) reveals cis-and trans-effects on gene expression in maize hybrid meristem tissue. Plant molecular biology, 66(5), pp.551-563.

He, Y., Wang, M., Dukowic-Schulze, S., Zhou, A., Tiang, C.L., Shilo, S., Sidhu, G.K., Eichten, S., Bradbury, P., Springer, N.M. and Buckler, E.S., 2017. Genomic features shaping the landscape of meiotic double-strand-break hotspots in maize. Proceedings of the National Academy of Sciences, 114(46), pp.1223112236.

Hiremath, P.J., Kumar, A., Penmetsa, R.V., Farmer, A., Schlueter, J.A., Chamarthi, S.K., Whaley, A.M., Carrasquilla- Garcia, N., Gaur, P.M., Upadhyaya, H.D. and Kavi Kishor, P.B., 2012. Large- scale development of cost- effective SNP marker assays for diversity assessment and genetic mapping in chickpea and comparative mapping in legumes. Plant journal, 10(6), pp.716-732.

Jiang, W., Bikard, D., Cox, D., Zhang, F. and Marraffini, L.A., 2013. RNA-guided editing of bacterial genomes using CRISPR-Cas systems. Nature biotechnology, 31(3), p.233.

Ji-hua, T., Wen-tao, T., Jian-bing, Y., Xi-qing, M., Yi-jiang, M., Jin-rui, D. and JianSheng, L., 2007. Genetic dissection of plant height by molecular markers using a population of recombinant inbred lines in maize. Euphytica, 155(1-2), pp.117-124.

Karen Sabadin, P., Lopes de Souza Júnior, C., Pereira de Souza, A. and Augusto Franco 
Garcia, A., 2008. QTL mapping for yield components in a tropical maize population using microsatellite markers. Hereditas, 145(4), pp.194-203.

Katti, M.V., Ranjekar, P.K. and Gupta, V.S., 2001. Differential distribution of simple sequence repeats in eukaryotic genome sequences. Molecular biology and evolution, 18(7), pp.1161-1167.

Khan, M.A., Kiran, U., Ali, A., Abdin, M.Z., Zargar, M.Y., Ahmad, S., Sofi, P.A. and Gulzar, S., 2017. Molecular markers and marker-assisted selection in crop plants. In Plant biotechnology: principles and applications (pp. 295-328). Springer, Singapore.

Knapp, S.J., 1991. Using molecular markers to map multiple quantitative trait loci: models for backcross, recombinant inbred, and doubled haploid progeny. Theoretical and Applied Genetics, 81(3), pp.333-338.

Knapp, S.J., Bridges, W.C. and Birkes, D., 1990. Mapping quantitative trait loci using molecular marker linkage maps. Theoretical and applied genetics, 79(5), pp.583-592.

Ku, L., Ren, Z., Chen, X., Shi, Y., Qi, J., Su, H., Wang, Z., Li, G., Wang, X., Zhu, Y. and Zhou, J., 2016. Genetic analysis of leaf morphology underlying the plant density response by QTL mapping in maize (Zea mays L.). Molecular breeding, 36(5), p.63.

Kump, K.L., Bradbury, P.J., Wisser, R.J., Buckler, E.S., Belcher, A.R., OropezaRosas, M.A., Zwonitzer, J.C., Kresovich, S., McMullen, M.D., Ware, D. and Balint-Kurti, P.J., 2011. Genome-wide association study of quantitative resistance to southern leaf blight in the maize nested association mapping population. Nature genetics, 43(2), p.163.

Leng, P., Ouzunova, M., Landbeck, M., Wenzel, G., Eder, J., Darnhofer, B. and Lübberstedt, T., 2018. Quantitative trait loci mapping of forage agronomic traits in six mapping populations derived from European elite maize germplasm. Plant
Breeding, 137(3), pp.370-378.

Li, R., Shi, F., Fukuda, K. and Yang, Y., 2009. Effects of salt and alkali stresses on germination, growth, photosynthesis and ion accumulation in alfalfa (Medicago sativa L.). Soil Science and Plant Nutrition, 56(5), pp.725-733.

Li, Y.G., Jiang, D., Xu, L.K., Zhang, S.Q., Ji, P.S., Pan, H.Y., Jiang, B.W. and Shen, Z.B., 2019. Evaluation of diversity and resistance of maize varieties to Fusarium spp. causing ear rot in maize under conditions of natural infection. Czech Journal of Genetics and Plant Breeding, 55(4), pp.131-137.

Lima, M.D.L.A., de Souza, C.L., Bento, D.A.V., De Souza, A.P. and CarliniGarcia, L.A., 2006. Mapping QTL for grain yield and plant traits in a tropical maize population. Molecular breeding, 17(3), pp.227-239.

Liu, J.J., Wei, Z. and Li, J.H., 2014. Effects of copper on leaf membrane structure and root activity of maize seedling. Botanical studies, 55(1), p.47.

Lu, D., Cai, X., Shi, Y., Zhao, J. and Lu, W., 2015. Effects of waterlogging after pollination on the physicochemical properties of starch from waxy maize. Food chemistry, 179, pp.232-238.

Lu, Y., Zhang, S., Shah, T., Xie, C., Hao, Z., Li, X., Farkhari, M., Ribaut, J.M., Cao, M., Rong, T. and Xu, Y., 2010. Joint linkagelinkage disequilibrium mapping is a powerful approach to detecting quantitative trait loci underlying drought tolerance in maize. Proceedings of the National Academy of Sciences, 107(45), pp.19585-19590.

Mandolino, C.I., D’Andrea, K.E., Olmos, S.E., Otegui, M.E. and Eyhérabide, G.H., 2018. Maize Nitrogen Use Efficiency: QTL Mapping in a US Dent $x$ ArgentineCaribbean Flint RILs population. Maydica, 63(1), p.17.

Mano, Y. and Omori, F., 2007. Breeding for flooding tolerant maize using" teosinte" as a germplasm resource. Plant Root, 1, pp.17-21. 
Martins, M.A., Tomasella, J. and Dias, C.G., 2019. Maize yield under a changing climate in the Brazilian Northeast: Impacts and adaptation. Agricultural water management, 216, pp.339-350.

Matsuoka, Y., Vigouroux, Y., Goodman, M.M., Sanchez, J., Buckler, E. and Doebley, J., 2002. A single domestication for maize shown by multilocus microsatellite genotyping. Proceedings of the National Academy of Sciences, 99(9), pp.60806084.

Melchinger, A.E., Messmer, M.M., Lee, M., Woodman, W.L. and Lamkey, K.R., 1991. Diversity and relationships among US maize inbreds revealed by restriction fragment length polymorphisms. Crop Science, 31(3), pp.669-678.

Moreira, R., Chenlo, F., Arufe, S. and Rubinos, S.N., 2015. Physicochemical characterization of white, yellow and purple maize flours and rheological characterization of their doughs. Journal of food science and technology, 52(12), pp.7954-7963.

Mu, X., Chen, Q., Chen, F., Yuan, L. and Mi, G., 2018. Dynamic remobilization of leaf nitrogen components in relation to photosynthetic rate during grain filling in maize. Plant Physiology and Biochemistry, 129, pp.27-34.

Mukhtar, M.S., Rahmanw, M.U. and Zafar, Y., 2002. Assessment of genetic diversity among wheat (Triticum aestivum L.) cultivars from a range of localities across Pakistan using random amplified polymorphic DNA (RAPD) analysis. Euphytica, 128(3), pp.417-425.

Nayak, S.N., Zhu, H., Varghese, N., Datta, S., Choi, H.K., Horres, R., JŘngling, R., Singh, J., Kishor, P.K., Sivaramakrishnan, S. and Hoisington, D.A., 2010. Integration of novel SSR and gene-based SNP marker loci in the chickpea genetic map and establishment of new anchor points with Medicago truncatula genome. Theoretical and Applied Genetics, 120(7), pp.1415-1441.

Poland, J.A., Bradbury, P.J., Buckler, E.S. and
Nelson, R.J., 2011. Genome-wide nested association mapping of quantitative resistance to northern leaf blight in maize. Proceedings of the National Academy of Sciences, 108(17), pp.68936898.

Prasanna, B.M. and Sharma, L., 2005. The landraces of maize (Zea mays L.): diversity and utility. Indian Journal of Plant Genetic Resources, 18(2), pp.155168.

Raihan, M.S., Liu, J., Huang, J., Guo, H., Pan, Q. and Yan, J., 2016. Multi-environment QTL analysis of grain morphology traits and fine mapping of a kernel-width QTL in Zheng58x SK maize population. Theoretical and applied genetics, 129(8), pp.1465-1477.

Rebourg, C., Chastanet, M., Gouesnard, B., Welcker, C., Dubreuil, P. and Charcosset, A., 2003. Maize introduction into Europe: the history reviewed in the light of molecular data. Theoretical and applied genetics, 106(5), pp.895-903.

Sachidanandam, R., Weissman, D., Schmidt, S.C., Kakol, J.M., Stein, L.D., Marth, G., Sherry, S., Mullikin, J.C., Mortimore, B.J., Willey, D.L. and Hunt, S.E., 2001. A map of human genome sequence variation containing 1.42 million single nucleotide polymorphisms. Nature, 409(6822), pp.928-934.

Saghai, M.M., Biyashev, R.M., Yang, G.P., Zhang, Q. and Allard, R.W., 1994. Extraordinarily polymorphic microsatellite DNA in barley: species diversity, chromosomal locations, and population dynamics. Proceedings of the National Academy of Sciences of the United States of America,91(12), pp.5466-5470.

Saghai, M.M., Biyashev, R.M., Yang, G.P., Zhang, Q. and Allard, R.W., 1994. Extraordinarily polymorphic microsatellite DNA in barley: species diversity, chromosomal locations, and population dynamics. Proceedings of the National Academy of Sciences of the United States of America,91(12), 
pp.5466-5470.

Schlötterer, C. and Tautz, D., 1992. Slippage synthesis of simple sequence DNA. Nucleic acids research,20(2), pp.211-215.

Showemimo, F.A., et al., (2007). Evaluation of divergence of agronomic and nutritional traits in quality protein maize.In Demanddriven technologies for sustainable maizeproduction in West and Central Africa. Proceedings of the fifth biennial regional maize workshop, IITA-Cotonou, Bénin, 3-6 May, 2005.WECAMAN/IITA, Ibadan, Nigeria. 515 pages.

Sibov, S.T., De Souza Jr, C.L., Garcia, A.A.F., Silva, A.R., Garcia, A.F., Mangolin, C.A., Benchimol, L.L. and De Souza, A.P., 2003. Molecular mapping in tropical maize (Zea mays L.) using microsatellite markers. 2. Quantitative trait loci (QTL) for grain yield, plant heigth, ear height and grain moisture. Hereditas, 139(2), pp.107-115.

Sobrino, B., Brión, M. and Carracedo, A., 2005. SNPs in forensic genetics: a review on SNP typing methodologies. Forensic science international, 154(2-3), pp.181194.

Soleimani, V.D., Baum, B.R. and Johnson, D.A., 2003. Efficient validation of single nucleotide polymorphisms in plants by allele-specific PCR, with an example from barley. Plant molecular biology reporter, 21(3), pp.281-288.

Sunyaev, S.R., Eisenhaber, F., Rodchenkov, I.V., Eisenhaber, B., Tumanyan, V.G. and Kuznetsov, E.N., 1999. PSIC: profile extraction from sequence alignments with position-specific counts of independent observations. Protein engineering, 12(5), pp.387-394.

Szalma, S.J., Hostert, B.M., LeDeaux, J.R., Stuber, C.W. and Holland, J.B., 2007. QTL mapping with near-isogenic lines in maize. Theoretical and Applied Genetics, 114(7), pp.1211-1228.

Tanksley S, Medino-Filho H, Rick C (1982) Use of naturally occurring enzyme variation to detect and map genes controlling quantitative traits in an interspecific backcross of tomato. Heredity 49:11-25

Tautz, D. and Renz, M., 1984. Simple sequences are ubiquitous repetitive components of eukaryotic genomes. Nucleic acids research, 12(10), pp.4127-4138.

Twumasi-Afriyie, S., Zelleke, H., Yihun, K., Asefa, B. and Tariku, S., 2002. Development and improvement of highland maize in Ethiopia. Enhancing the Contribution of Maize to Food Security in Ethiopia, EARO and CYMMIT, Addis Ababa, pp.31-38.

Vigouroux, Y., Mitchell, S., Matsuoka, Y., Hamblin, M., Kresovich, S., Smith, J.S.C., Jaqueth, J., Smith, O.S. and Doebley, J., 2005. An analysis of genetic diversity across the maize genome using microsatellites. Genetics, 169(3), pp.1617-1630.

Wada N, Feng C, Gulati A (2008) Introduction and overview. In: Gulati A, Dixon J (eds) Maize in Asia: changing markets and incentives. Academic Foundation, New Delhi

Wang, R.L., Stec, A., Hey, J., Lukens, L. and Doebley, J., 1999. The limits of selection during maize domestication. Nature, 398(6724), pp.236-239.

Wang, S., Wang, J., Yu, J. and Wang, S., 2014. A comparative study of annealing of waxy, normal and high-amylose maize starches: The role of amylose molecules. Food chemistry, 164, pp.332338 .

Wang, X., Brown, I.L., Evans, A.J. and Conway, P.L., 1999. The protective effects of high amylose maize (amylomaize) starch granules on the survival of Bifidobacterium spp. in the mouse intestinal tract. Journal of Applied Microbiology, 87(5), pp.631-639.

Warburton, M.L., Brooks, T.D., Windham, G.L. and Williams, W.P., 2011. Identification of novel QTL contributing resistance to aflatoxin accumulation in 
maize. Molecular Breeding, 27(4), pp.491-499.

Wenz, H.M., Robertson, J.M., Menchen, S., Oaks, F., Demorest, D.M., Scheibler, D., Rosenblum, B.B., Wike, C., Gilbert, D.A. and Efcavitch, J.W., 1998. High-precision genotyping by denaturing capillary electrophoresis. Genome research, 8(1), pp.69-80.

Westman, A.L. and Kresovich, S., 1997. Use of molecular marker techniques for description of plant genetic variation. Biotechnology in agriculture series, pp.9-48.

Wu, K.S. and Tanksley, S.D., 1993.
Abundance, polymorphism and genetic mapping of microsatellites in rice. Molecular and General Genetics $M G G, 241$ (1-2), pp.225-235.

Xie, L., Zhang, J., Wang, Q., Meng, C., Hong, J. and Zhou, X., 2011. Characterization of maize chlorotic mottle virus associated with maize lethal necrosis disease in China. Journal Phytopathology, 159(3), pp.191-193.

Zheng, Z.P. and Liu, X.H., 2013. Genetic analysis of agronomic traits associated with plant architecture by QTL mapping in maize. Genet Mol Res, 12(2), pp.124353.

\section{How to cite this article:}

Anand Kumar and Vivudh Pratap Singh. 2020. Maize Genetic Diversity: Utilization of Molecular Markers in Genetic Diversity. Int.J.Curr.Microbiol.App.Sci. 9(02): 1948-1959. doi: https://doi.org/10.20546/ijcmas.2020.902.222 